Available online on 15.05 .2020 at http://jddtonline.info
Open Access to Pharmaceutical and Medical Research
unrestricted non-commercial use, provided the original work is properly cited

Open $\odot$ Access

Research Article

\title{
Modulatory Effects of Honey on Gastric Acidity and Plasma Postprandial Bicarbonate in Wistar Rats
}

\author{
*Uchechukwu Ifeanyichukwu Apugo and Onyebuchi Obia \\ Department of Human Physiology, Faculty of Basic Medical Sciences, University of Port Harcourt, Nigeria
}

\begin{abstract}
Introduction: Honey is a naturally occurring sweet substance of plant origin composed mainly of fructose, glucose, water, antioxidants and other constituents. Its enormous constituents confer it with medicinal and nutritive usefulness.

Objectives: To assess the modulatory effects of honey on gastric acidity and plasma postprandial bicarbonate in wistar rats.

Method: A total of 24 male wistar rats weighing 200-250g were divided into four groups of six rats each; Group I served as control, Group II received $50 \%$ Honey $(10 \mathrm{ml} / \mathrm{kg})$, Group III received omeprazole $(20 \mathrm{mg} / \mathrm{kg})$ and Group IV received a combination of 0 meprazole and Honey. The $\mathrm{pH}$ of gastric effluents in each rat was measured 15, 30 and 45mins using a pH meter after administration of the respective substances in each group.

Result and Discussion: Both honey and omeprazole respectively caused significant increases in the pH of gastric effluents, however, while that of honey was slow and steady, that of omeprazole was sharp and sustained. The 45-min pH level of omeprazole group was significantly higher than that of honey group. The combined group showed an initial sharp rise similar to omeprazole alone but gradually declined in the succeeding time interval. A combination of omeprazole and honey resulted in $27 \%$ reduction in the postprandial serum bicarbonate whereas omeprazole alone caused $41 \%$ reduction
\end{abstract}

Conclusion: The present study concludes that honey modulated gastric pH to levels possibly favourable to gastric function by either a direct action of reducing gastric acidity or acting as an antacid or both. Honey therefore could be described as a buffer in omeprazole stimulated gastric acid inhibition and a potential antacid.

Keywords: Honey, Gastric acidity, Gastric $\mathrm{pH}$, bicarbonate.

Article Info: Received 07 March 2020; Review Completed 10 April 2020; Accepted 16 April 2020; Available online 15 May 2020

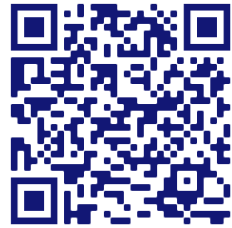

Cite this article as:

Apugo UI, Obia 0, Modulatory Effects of Honey on Gastric Acidity and Plasma Postprandial Bicarbonate in Wistar Rats, Journal of Drug Delivery and Therapeutics. 2020; 10(3):48-50 http://dx.doi.org/10.22270/jddt.v10i3.3978

\section{*Address for Correspondence:}

Port Harcourt, Nigeria

Uchechukwu Ifeanyichukwu Apugo, Department of Human Physiology, Faculty of Basic Medical Sciences, University of

\section{INTRODUCTION}

The physiology of the stomach depends largely on the rate of secretion of gastric juice, the integrity of the gastric mucosa as well as its musculature, all of which collectively act as barriers against offensive agents such as non-steroidal antiinflammatory drugs, cytotoxic agents and Helicobacter pylori infection. Gastric ulcerations would occur when the causative factors outweigh the defensive factors [1]. However, there are several secretory glands in the stomach which ultimately secrete into the gastric pits. Of these glands, oxyntic gland is made up of highly secretory cells called parietal cells that secrete gastric acid [2,3]. Other secretory cell types of the stomach include; the mucus neck cells which secrete mucus, the peptic cells which secrete pepsinogen, the ' $G$ ' cells which secrete gastrin $[4,5]$.
The gastric acid, though has its essential physiological roles in humans, its excessive secretion is implicated in peptic ulcerations [3] especially as this may overwhelm the gastric mucosal protective mechanisms. The secretion of gastric acid by the parietal cells is driven by an energy dependent process requiring $\mathrm{H}^{+}-\mathrm{K}^{+}$-ATPase [2]. Acetylcholine, gastrin and histamine are well known stimulants of gastric acid secretion that ultimately play physiological role in regulating the secretion of gastric acid [6]. This is regulated either by a negative feedback mechanism via stimuli originating in the brain or locally by the entero-gastric reflex [7]. The gastric acid thus secreted activates pepsinogen and also play a role in innate immunity by destroying bacteria and other microbes in the stomach. The number of acid secreting parietal cells is genetically determined, however, studies using guinea pig suggest that there could be parietal cell hyperplasia following continuous stimulation of the gastric mucosa with histamine [8]. 
Honey is a naturally occurring sweet substance synthesized from plants by bees. It has enormous economic and health benefits [9] and is consumed in virtually all countries of the world. Its health benefits are widely accepted because it contains; enzymes, vitamins, minerals, flavonoids and several other constituents [10,11]. Studies have proven that honey consumption could be beneficial to patients with peptic ulcerations due to its content of antioxidants. In a study using manuka honey, Almasaudi et al., [12] reported that honey prevented ethanol-induced gastric ulceration by preserving both the enzymatic and non-enzymatic antioxidants and also by inhibiting lipid peroxidation.

\section{Aim and objectives}

This study was aimed at investigating the effects of administration of honey on gastric acidity and plasma postprandial bicarbonate secretion in male wistar rats.

\section{MATERIALS AND METHODS}

The research experiment was performed in the animal house of the department of Human Physiology, faculty of Basic Medical sciences, University of Port Harcourt, Nigeria following approval by the Research ethics committee of the Centre for Research Management and Development, University of Port Harcourt. Fresh commercial quality honey sample was obtained from the Department of Forestry, University of Port Harcourt, Nigeria. It was unprocessed, pure and of good quality. The honey was subsequently reconstituted by diluting with distilled water to produce $50 \%$ (v/v) honey. Omeprazole (Strides Shasun Ltd., Mumbai: India) was procured and used in the investigation. All other reagents used were of analytical grade.

\section{Experimental Animals and Design}

This experiment involved 24 male wistar rats divided into 4 groups of 6 rats each. Group 1 served as control and received distilled water; Group 2 received $10 \mathrm{ml} / \mathrm{kg}$ of $50 \%$ honey; Group 3 received 20mg/kg of omeprazole [13]; while Group 4 received a combination of omeprazole $(20 \mathrm{mg} / \mathrm{kg})$ and $50 \%$ honey $(10 \mathrm{ml} / \mathrm{kg})$.

\section{Gastric Acid Determination}

Gastric acid secretion was determined by the modified method of Ghosh and Schild[14] and as used by Osim et al., [15]. Each animal was first positioned on the dissecting table by using pins to restrain the limbs and then anaesthetized using $25 \%$ urethane. The trachea was cannulated to maintain airway throughout the experiment. An abdominal incision was made to access the stomach from where a semitransection was made at the level of the pylorus to which a cannula was inserted and connected to a beaker to collect gastric effluents. An oro-esophageal tube was then inserted into the mouth and oesophagus for perfusion of pre-warmed distilled water to remove food debris in the stomach. This was then followed by perfusion of the respective substances every $15 \mathrm{mins}$ for $45 \mathrm{mins}$ according to their groups. The $\mathrm{pH}$ of the obtained samples containing gastric secretions was determined with the aid of a $\mathrm{pH}$ meter (Model PHS-3C, Hanna: England). Blood sample was collected from each rat at $45 \mathrm{mins}$ to determine the post-prandial bicarbonate concentration using colorimetric method [16].

\section{Statistical Analysis}

Statistical analysis was done using SPSS vs 20.0 (SPSS incorporated, Chicago, Illinois, USA) and Microsoft excel. Tables were used to represent data. Continuous variables were represented as mean \pm SEM while discrete variables were represented in percentages. Comparison of means was done using one-way ANOVA test and differences in values considered statistically significant at $p<0.05$.

\section{RESULTS AND DISCUSSION}

\section{Effect of honey on the $\mathrm{pH}$ of gastric effluents}

The physiologic characteristic of the stomach relies mainly on the rate of secretion of gastric acid, thickness of the gastric mucosa and the presence of gastric trefoil peptides [17]. In the present study, the control showed no significant change in the $\mathrm{pH}$ from $15 \mathrm{mins}$ to $45 \mathrm{mins}$ with a value of 5.96 at $45 \mathrm{mins}$. The $\mathrm{pH}$ of honey used in this experiment was considerably similar to previous reports [18]. However, with honey administration, the $\mathrm{pH}$ of gastric effluent increased gradually reaching a maximum of 6.71 after $45 \mathrm{mins}$ (Table 1). To prevent gastric ulcerations, the gastric mucosal protective agents must be reinforced to prevent being overcome by the causative agent $[1,19]$. Therefore, one of the modalities in prevention and treatment of gastric ulcerations would be to reduce the rate of gastric acid secretion or to neutralize it in the gastric mucosa. Using honey alone, the initial $\mathrm{pH}$ (at 15mins) was significantly higher than that of the control and increased gradually within the 45-min period. This gradual change in the $\mathrm{pH}$ and by implication a gradual reduction in gastric acid showed that honey might have a slow onset of action in reducing gastric acid secretion.

Table 1: Effect of honey on the pH of gastric effluents

\begin{tabular}{|c|c|c|c|c|}
\hline Time (mins) & Control & $\mathbf{5 0 \%}$ honey & $\begin{array}{c}\text { Omeprazole } \\
(\mathbf{2 0 m g} / \mathbf{k g})\end{array}$ & $\begin{array}{l}\text { Omeprazole (20mg/kg) + } \\
\mathbf{5 0 \%} \text { Honey }\end{array}$ \\
\hline $\mathbf{1 5}$ & $5.96 \pm 0.09$ & $6.27 \pm 0.24^{*}$ & $6.90 \pm 0.02^{*}$ & $6.90 \pm 0.02^{*}$ \\
\hline $\mathbf{3 0}$ & $5.96 \pm 0.09$ & $6.56 \pm 0.10^{*}$ & $6.98 \pm 0.08^{*}$ & $6.83 \pm 0.02^{*}$ \\
\hline $\mathbf{4 5}$ & $5.96 \pm 0.09$ & $6.71 \pm 0.01^{*} \#$ & $6.98 \pm 0.01^{*}$ & $6.78 \pm 0.01^{*}$ \\
\hline
\end{tabular}

$N=6$; *significant change compared to $\mathrm{pH}$ of control, \# significant change compared to the $\mathrm{pH}$ at $15 \mathrm{mins}$.

Omeprazole, the well-known proton pump inhibitor caused an initial sharp rise in the gastric $\mathrm{pH}$ within $15 \mathrm{mins}$ of administration which was sustained until the 45-min period. A combination of honey and omeprazole showed an initial significant but sharp rise in gastric $\mathrm{pH}$ similar to that caused by omeprazole alone and thereafter it gradually declined in the succeeding $30 \mathrm{mins}$ interval. Honey alone resulted in a slow but steady increase in the gastric $\mathrm{pH}$ which was however; lower than the omeprazole group at 45 mins. The present study suggests that honey might have acted synergistically with omeprazole to cause a rise in gastric $\mathrm{pH}$ and that the presence of honey would control the $\mathrm{pH}$ to levels that are favourable to gastric function. Gastric acid is involved in innate immunity, aids digestion (by activation of pepsinogen), enhances the absorption of certain micronutrients and vitamins including iron, calcium, and 
vitamin $\mathrm{B}_{12}{ }^{[20]}$. Therefore, prolonged use of omeprazole alone might reduce gastric acid continuously to levels that could impair these aforementioned processes leading to indigestion of certain proteins, increased susceptibility to infections in the gastrointestinal tract, micronutrient deficiency, osteoporosis and other consequences. This therefore, underscores the need for honey in the drug treatment of peptic ulcer. The present study thus reports that the mechanism of action of honey in reducing gastric acidity could probably be due to either its direct action of reducing acid secretion or by acting as an antacid to neutralize gastric acidity or both.

Table 2 Post-prandial serum $\mathrm{HCO}_{3}$ - concentration

\begin{tabular}{|l|c|c|}
\hline Groups & Bicarbonate concentration (mmol/l) & \% Relative change \\
\hline Control & $30.23 \pm 1.09$ & 0 \\
\hline $50 \%$ honey & $26.30 \pm 1.01^{*}$ & -13 \\
\hline Omeprazole $(20 \mathrm{mg} / \mathrm{kg})$ & $17.70 \pm 0.80^{*}$ & -41 \\
\hline Omeprazole $(20 \mathrm{mg} / \mathrm{kg})+50 \%$ honey & $21.93 \pm 0.33^{*} \#$ & -27 \\
\hline
\end{tabular}

$\mathrm{N}=6$; *significant compared to control, \# significant compared to omeprazole group

To determine the activity of honey in inhibiting gastric acid secretion, the postprandial serum bicarbonate was measured. This is because gastric acid secretion can also be assessed indirectly by determining the post-prandial plasma bicarbonate concentration due to the activity of the proton pump. So that following a meal, the level of plasma bicarbonate is directly proportional to the level of gastric acidity [21]. In the present study, honey administration caused a $13 \%$ reduction in the $45 \mathrm{~min}$-postprandial serum bicarbonate concentration relative to the control (Table 2). However, administration of omeprazole alone resulted in as much as $41 \%$ reduction in post-prandial bicarbonate relative to the control but when honey was co-administered with omeprazole, only $27 \%$ reduction was noted relative to control. Again, prolonged administration of omeprazole alone could cause severe reduction in plasma bicarbonate (or metabolic acidosis) and its consequences but its coadministration with honey helped to improve the level of bicarbonate and thus could prevent the problems associated with low bicarbonate (such as fatigue, confusion, tachypnoea, etc.).). Results of the present study therefore indicates that coadministration of honey and omeprazole controlled both the acid output in the gastric lumen and the post-prandial serum bicarbonate suggesting that honey possibly moderated the activity of the proton pump.

\section{CONCLUSION}

The present study concludes that honey modulated gastric $\mathrm{pH}$ to levels possibly favourable to gastric function by either a direct action of reducing gastric acidity or acting as an antacid or both. Honey therefore could be described as a buffer in omeprazole stimulated gastric acid inhibition.

\section{REFERENCES}

1. Mohamed AL, Ali, HE, Ahmed EN, Yaser HAE, Soad KA, Shaker AM, Protective Effects of Miswak (Salvadorapersica) against Experimentally Induced Gastric Ulcers in Rats, Oxidative Medicine and Cellular Longevity, 2018; https://doi.org/10.1155/2018/6703296

2. Forte JG, ZhuL, Apical Recycling of the Gastric Parietal Cell H, K-ATPase, Annual Review of Physiology, 2010; 72, 273-96.

3. Holzer P, Role of visceral afferent neurons in mucosal inflammation and defense, Current Opinion in Pharmacology, 2007; 7:563-569.

4. Kim TH, Shivdasani RA, Stomach development, stem cells and disease, Development, 2016; 143:554-565.

5. Eicher AK, Berns HM, Wells JM, Translating Developmental Principles to Generate Human Gastric Organoids,Cellular and Molecular Gastroenterology and Hepatology, 2018; 5:353-363
6. Beales, IL, Regulation of gastric function by gastrin releasing peptide, Gut, 2002; 50(6):897-898.

7. Schubert ML, Peura DA, Control of Gastric Acid Secretion in Health and Disease, Gastroenterology, 2008; 134(7):1842 - 60

8. McLeod R, Gertner S, Hey J, Production by R- $\alpha$ methylhistamineof a histamine $\mathrm{H} 3$ receptor mediated decrease in basalvascular resistance in guinea-pigs, British Journal of Pharmacology, 1993; 110, 553-558

9. Abeshu MA, Geleta B, Medicinal uses of honey, Biology and Medicine, 2016; 8(2):1-7.

10. Terrab A, Hernanz D, Heredia FJ,Inductively coupled plasma optical emission spectrometric determination of minerals in thyme honeys and their contribution to geographical discrimination,Journal of Agriculture and Food Chemistry, 2004; 52:3441-3445

11. Singh MP, Chourasia HR, Agarwal M, Malhotra A, Sharma M, Sharma D,Khan S, Honey as complementary medicine: - A review,International Journal of Pharmaceutical and Biological Sciences, 2012; 3(2):12-31

12. Almasaudi SB, El-Shitany NA, Abbas AT, Abdel-dayem UA, Ali SS, Al Jaouni SK, Harakeh S, Antioxidant, anti-inflammatory, and antiulcer potential of manuka honey against gastric ulcer in rats. Oxidative medicine and cellular longevity, 2015;Doi: $10.1155 / 2016 / 3643824$

13. Hasanin $\mathrm{AH}$, Impact of omeprazole on bone remodeling in normal and ovariectomized Wistar rats. European Review for Medical and Pharmacological Sciences, 2014; 18(13):48-56

14. Ghosh MS, Schild HO, Continuous recording of acid gastric secretion in the rat,Brazilian Journal of Pharmacology and Chemotherapy, 1958; 13:54-61

15. Osim EE, Alagwu EA, Nneli RO, Okwari, 00, Biliary secretion in albino rats following chronic honey intake,Nigerian Journal of Physiological Sciences, 2009; 24(2):210

16. Erchinger F, Engjom T, Tjora E, Aksnes L, Dimcevskir G, Gudbrandsen OA,Automated spectrophotometric bicarbonate analysis in duodenal juice compared to the back titration method, Pancreatology, 2017; 16(2):231-237

17. Wong WM, Poulson R,Wright NA,Trefoil peptides, Gut, 1999; 44(6):890-895

18. Manyi-Loh CE, Clarke AM, Ndip RN, An overview of honey: Therapeutic properties and contribution in nutrition and human health, African Journal of Microbiology Research, 2011; 5(8):844-852.

19. Potrich FB, Allemand A, Da Silva LM, DosSantosa AC, Baggio $\mathrm{CH}$, Freitas CS, Mendes DAG, Andre E, Werne MF, Marques MC, Antiulcerogenic activity of hydroalcoholic extract of AchilleamillefoliumL.: Involvement of the antioxidant system. Journal of Ethnopharmacology, 2010; 130:85-92.

20. Schubert LM, Functional anatomy and physiology of gastric secretion. Current opinion in gastroenterology 2017; 31(6):479-485. Doi: 10.1097/MOG.0000000000000213

21. Flemstrom G, Garner A, Gastroduodenal HCO3 transport: characteristics and proposed role in acidity regulation and mucosal protection. American Journal of Physiology, 1982; 243:183-93. 